Annals of Warsaw University of Life Sciences - SGGW

Land Reclamation No 43 (1), 2011: 47-55

(Ann. Warsaw Univ. of Life Sci. - SGGW, Land Reclam. 43 (1), 2011)

\title{
Effect of hydrogel on the turf grass species growing under salt stress
}

\author{
HADAM ANNA $^{1}$, WROCHNA MARIOLA ${ }^{2}$, KARACZUN ZBIGNIEW $^{1}$ \\ ${ }^{1}$ Department of Environmental Protection, Warsaw University of Life Sciences - SGGW \\ ${ }^{2}$ Laboratory of Basic Research in Horticulture, Warsaw University of Life Sciences - SGGW
}

\begin{abstract}
Effect of hydrogel on the turf grass species growing under salt stress. Hydrogels can absorb huge amount of water and so are able to decrease the drought stress in plants. They are used in horticulture and agriculture for years. It is possible that they may be applied also on the grass near - road areas. Because of water deficient and high salinity growth of plants in these conditions is however hard. Meanwhile, too high concentration of ions in soil can decrease efficacy of hydrogel, since it can absorb water and cations as well. Nevertheless there is still too less studies on such problem. From this point of view it seems that the complex assessment of hydrogels effect on urban lawn grass is needed. The aim of the study was therefore the evaluation of grasses condition after their cultivation under salt stress with and without hydrogels amendment. Experience was conducted for four months in the controlled green house conditions. The efficacy of hydrogels amendment was measured by the grass reactions (turfs height, fresh matter content and level of membranes injury) on three levels of salinity. The results allowed concluding that, concentration of the road de- icing salt was the main factor, which affected condition of all tested species. This reaction was independent on the presence of hydrogel. Nevertheless under low and medium saline conditions watersorbent weakened significantly influence of salt stress on the grass.
\end{abstract}

Key words: drought, water sorbent, salt stress, urban lawn grass.

\section{INTRODUCTION}

Hydrogels are polymer substances which are able to absorb huge amount of water (Trippei et al. 1991). Amended to soil they increase its watercapicity, decrease evapotransporation and allow plants to mitigate the drought stress (Leciejewski 2008; Bartnik 2008). This innovative method is known to be: easy, cheap and ecological. It lets to decrease costs of irrigation and humans work, enables to safe water and energy with holding the chemical safety for the environment (Benedycka and Nowal 1998; Sroka 2004; Diener and Hey 2005; Baranowski 2006).

Nowadays, soil supersorbents are used commonly in horticulture and agricultre, where they precipite: growth, rooting and leafing of many species, cultivated around the world (tomatos, cotton, tabacco) (Wallace and Wallace 1986; Sroka 2004; Al-Humaid 2005). It is also known that watersorbents help to recultivate the degraded areas - even there, where flora was absolutely devastated, they provide the revegatation (Paluszek and Żembrowski 2006).

Above adventages suggest therefore that using of hydrogels could be succesfully broaden to the other domains, especially there, where drought problems are frequent. Such practices however have not been established well yet, because effectiveness of hydrosorbents depends often on species (Wallace and Wallace 1986; Sroka 2004; Akhter et al. 2004; Al-Humaid 2005). 
For this reason Department of Environmental Protection (DEP) SGGW started evaluation of using hydrogels on the grass species present in the near - road areas. Lawn grasses are the most common green areas near the road sides and play an important role in landfill landscaping and shaping the microclimate conditions (Wysocki and Stawicka 2005; Pawluśkiewicz 2009). Unfortunately many stresses, especially drought, decrease their growth and condition (Wysocki 2008; Pawluśkiewicz 2009), what with high costs of irrigation cause that some innovative cultivation is needed.

Preliminary, greenhouse studies provided by DEP in 2009 allowed to concluded, that hydrogel influenced postively on germination, growth and dry matter content of tested grass species cultivated under simulated drought stress. It was also demonstrated that amendment of watersorbent make it possible to limit the watering frequence for tested plants from 3 to 1 per week and thanks to that to decrease costs of their irrigation for 3.5 times (Hadam 2010).

Nevertheless it should be also pointed that apart form the water hydrogels can absorb also cations (Benedycka and Nowal 1998), what in dependend on species, may decrease watersorbents efficacy in the drought resistance (Akhter et al. 2004). It is therefore possible that, high concentration of sodium in the roadside soils, resulting from using salts for de-icing (Wrochna et al. 2010), may exclude the relevance for using hydrogels on the near - road grasslands. This issue however has not been investigated yet.

The aim of the study was therefore the assessment of the grass reaction on the exposure to the soil salinity during greenhouse cultivation with and without hydrogels additive.

\section{MATERIAL AND METHODS}

The study was conducted for four months in a greenhouse of the Faculty of Horticulture and Landscape Architecture, Warsaw University of Life Sciences.

The experimental substrate, based on: sand, peat and horticultural soil (in proportion 1:1:1), was divided into two portions - with or without hydrogel amendment. The hydrogel was added in the amount required by the manufacturer (2 $\mathrm{g} / \mathrm{L}$ of substrate).

Such prepared substrates were filled in the pots $(12 \mathrm{~cm}$ diameter and volume $0.8 \mathrm{dm}^{3}$ ) and then were sown with one of the species, which are known to be the most common in the near- road areas:

- red fescue (Festuca rubra L.) cv. Raisa $(0.086 \mathrm{~g}$ of seeds/ pot),

- kentucky bluegrass (Poa pratensis L.) cv. Jarotka (0.074 g of seeds/ pot),

- perennial reygrass (Lollium perenne L.) cv. Accent $(0.123 \mathrm{~g}$ of seeds/ pot).

Number of seeds planted per pot depended on the: seedling emergence and seedling purity of each species, assessed by the Plant Breeding and Acclimatization Institute.

After a month plants cultivated with and without hydrogels amendment were treated with water salt solutions using the "Kłodawska" road de-icing salt (containing $97 \% \mathrm{NaCl}$ ) in concentrations of $0 \mathrm{~g} \cdot \mathrm{dm}^{-3}$ (control pots), $5 \mathrm{~g} \cdot \mathrm{dm}^{-3}$ and $10 \mathrm{~g} \cdot \mathrm{dm}^{-3}$. On the basis of the salinity curve for used substrate the electricity conductance was obtained there- 
fore as medium $\left(5.45 \mathrm{mS} \cdot \mathrm{cm}^{-1}\right)$ or high $\left(9,91 \mathrm{mS} \cdot \mathrm{cm}^{-1}\right)$ (Kreeb 1979). The control pots (without salt solution) were watered only, nevertheless its electrocicity conductance was also measured and it appeared to be a low saline $(\mathrm{EC}=1.30$ $\left.\mathrm{mS} \cdot \mathrm{cm}^{-1}\right)$.

Effectiveness of hydrogel under saline conditions was assessed after four months on the basis of the grass condition, characterised by the following parameters:

- turfs height [cm],

- fresh matter content of the plants above - ground [g /pot],

- increased membrane injury in compare to the control (plants not treated with the road de- icing salt) [\%].

Above parameters are commonly used in assessments of plants reaction on the stressed environmental conditions (Żurek 2006; Pawluśkiewicz 2009).

Measurements were conducted in 4 replications, where replication was a single pot with each grass species planted with or without hydrogels amendment and treated with the salt solution as was written above.

Results obtained from the study were analyzed statistically using the two factorial analysis of variance (ANOVA) of the Statgraphics 4.1 Plus software. Significance of differences between the combinations was examined with t-Student test at $\alpha=0.05$. Results show the mean values 4 replications.

During whole experiment plants were watered to the optimal level on the basis of the measurments conducted by soil moisture meter (ECHO - EC5). Grass were also mowing - once a week to 5 cm height.
The temperature and air humidity in the greenhouse were measured everyday (termohygrometer EPI 8703) and fluctuated from 22.9 to $35.0^{\circ} \mathrm{C}$ and $32.5-42.2 \%$.

\section{RESULTS AND DISCUSSION}

Figures present effect of soil salinity in the presence and absence of hydrogels amendement on the: height (Fig. 1), fresh matter content (Fig. 2) and percantage of membrane injury (Fig. 3) in red fescue Raisa, kentucky bluegrass Jarotka and perennial reygrass Accent.

The obtained results confirmed earlier observations (Wrochna et al. 2005), that soil salinity has negative effect on the growth and development of plants. Because of disturbing physiological and biochemical processes, it results, among the others, in: lower growth, decreased biomass production and increased membrane injury (Alpaslan and Gunes 2001; Morant-Manceau et al. 2004; Kacperska 2005). It was shown that concentration of the road- de- icing salt was the main factor, which affected all tested species. Independent on the water sorbents presence height and fresh matter content of red fescue Raisa, kentucky bluegrass Jarotka and perennial reygrass Accent decreased significantly with increase of the salt concentration (Figs. 1-2). It was also observed that, in both cases - in pots with and without sorbents additive, the higher level of salinity was simulated, the significantly higher turfs membrane injury was indicated (Fig. 3).

It can be therefore concluded that additive of the road de- icing salt decreased also ability of the hydrogel in improving condition of the tested grass species, probably, due to disturbing its water 


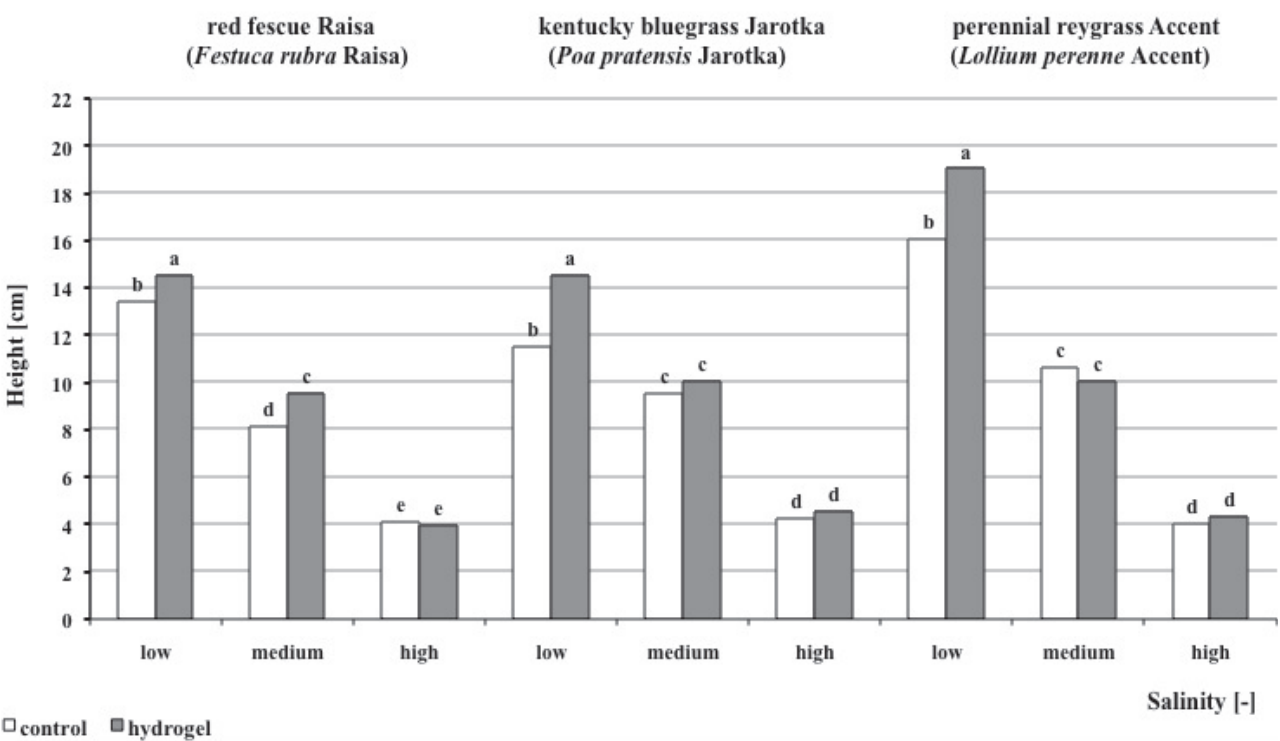

FIGURE 1. Influence of salinity on the turfs height of the grass species cultivated with and without (control) hydrogels amendment. Different letters show statistically significant differences between means within each species

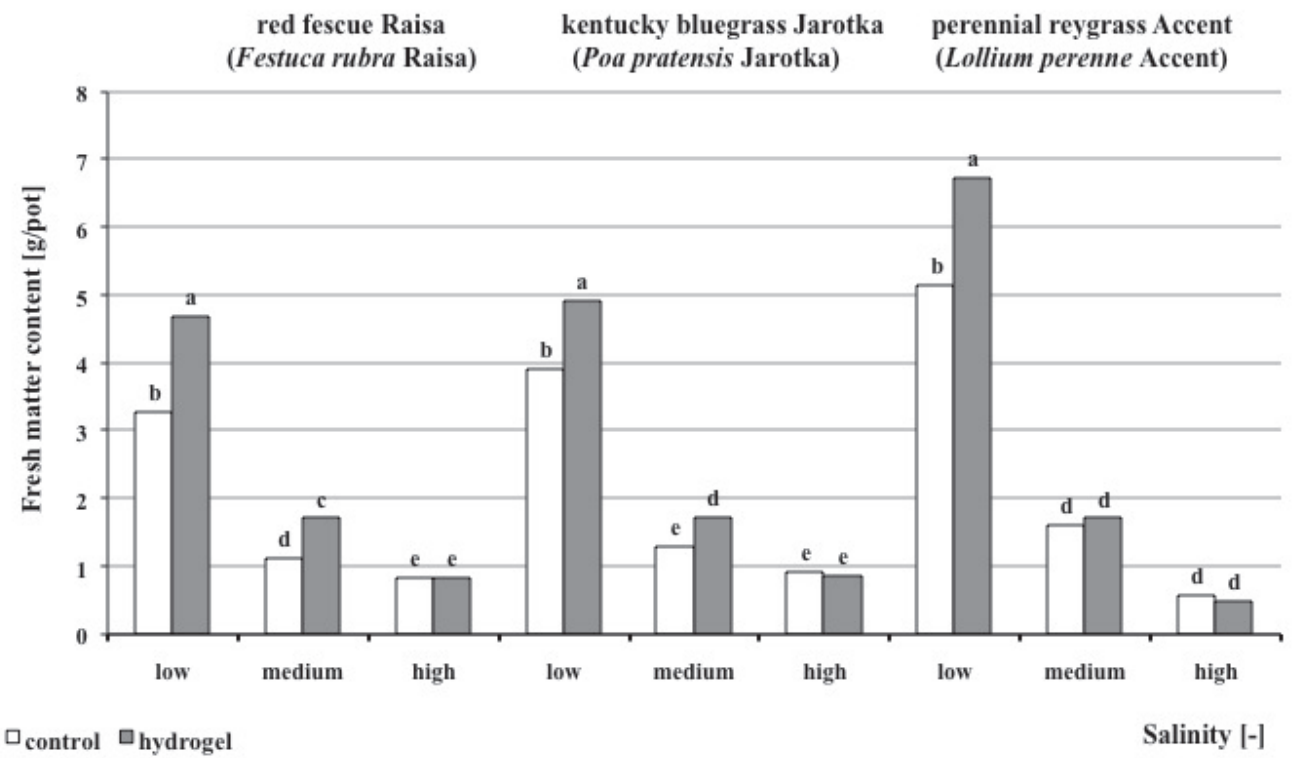

FIGURE 2. Influence of salinity on the fresh matter content of the grass species cultivated with and without (control) hydrogels amendment. Different letters show statistically significant differences between means within each species 


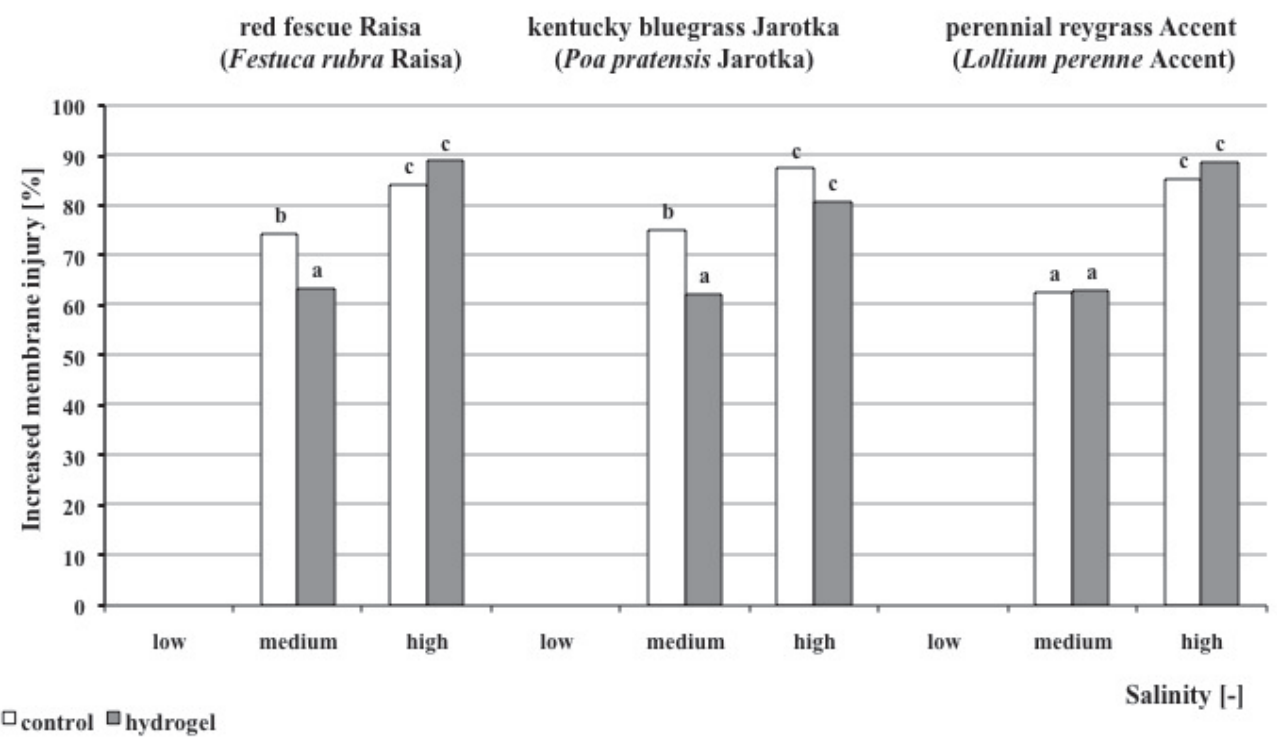

FIGURE 3. Influence of salinity on increased membrane injury of the grass species cultivated with and without (control) hydrogels amendment. Different letters show statistically significant differences between means within each species

absorbing abilities. Johnson (1984) and Asady et al. (1985) provided that chemicals and ions can adversely affect the function of hydrogels. It was also observed that its water retention was significantly lowered when the saline water was used (Akhter et al. 2004).

Nevertheless presented studies indicated also that, to the certain level of salinity, hydrogel can still enable some of the tested species to tolerate the salt stress. Under low saline conditions (EC $=1.30 \mathrm{mS} \cdot \mathrm{cm}^{-1}$ ) turfs height and fresh matter content of all tested species cultivated with the sorbents amendment was significantly greater than those without hydrogel. In the pots with the medium concentration of salt $\left(5 \mathrm{~g} \cdot \mathrm{dm}^{-3}\right)$ similar reaction on the watersorbents amendment was observed in the height and fresh matter content of red fescue (Figs. 1-2) and in the fresh matter production of kentucky bluegrass (Fig. 2). In such conditions hy- drogel decreased significantly also their membrane injury, from above $70 \%$ (in pots without hydrogel) to about $60 \%$ (Fig. 3). Similar observations have been reported by Hameda et al. (1995), who showed that under glasshouse conditon incorporation of hydrogel into sand has enabled cotton and maize to be grown in the saline solutions. It was also investigated that water sorbents amendment improved salt tolerance of certain other horticultural crops, including: tomato, cucumber, lettuce and bean (Hameda et al. 1990; Kant and Turan 2010). Despite above, under the medium salt stress hydrogel did not influenced on perennial reygrass. Lollium perenne is however known to be more tolerant to salinity than the other tested species (Alshammary et al. 2004; Wu et al. 2005). It may therefore explain why its all examined parameters were in pots with and without hydrosorbent comparable (Figs. 1-3). 
Because of the vulnerability on the salt stress, grass species are usually not reccomended on the highly salined areas (Pawluśkiewicz 2009). Presented results showed that hydrogel does not support their growth in such conditions. Height and fresh matter content of all tested species cultivated with the sorbents additive was comparably low with the controls (without hydrogel). Salt concentration of $10 \mathrm{~g} \cdot \mathrm{dm}^{-3}$ increased also grass membrane injury - to the high level above $80 \%$ in all species, independent on the hydrogels presence. It is possible that high concentration of sodium cations could saturated hydrogels matrix to that level, in which it was unable to absorb water (Akhter et al. 2004). In such conditions water sorbent was therefore unable to provide optimal substrates humidity and it could not amend condition of cultivated species.

\section{CONCLUSIONS}

1. Presented results allowed to conclude that additive of the road de- icing salt decreased efficacy of hydrogel in improving condition of the tested grass species.

2. Independent on the hydrogels amendment concentration of the road de-icing salt was the main factor which affected the: growth, fresh matter content and level of membrance injury in all tested species (red fescue Raisa, kentucky bluegrass Jarotka and perennial reygrass Accent). The higher dose of salt was added to the pots, the weaker condition of grass was observed - in both cases - with and without hydrogel.
3. Nevertheless hydrogel was able to improve condition of plants during cultivation under low and medium salt stress. Its efficacy depended however on the tested grass species and examined parameter.

4. Under low saline conditions hydrogel was the most efficacy. Growth and fresh matter content of all studied species cultivated with its amendment was higher than in the control - without hydrosorbent.

5. Under medium saline conditions efficacy of hydrogel was worse, but it lowered the growth inhibition of red fescue. It also increased the fresh matter production and decreased membranes injury of red fescue and kentucky bluegrass. Only perennial reygrass was not affected by the water sorbents amendment in such conditions. However this may result from its own ability to tolerate the salinity.

6. Hydrosorbent was indicated to be inefficient in the highly salined pots. Independent on the tested species, turfs height, fresh matter content and level of membranes injury were highly affected by the salt stress in all pots - with and without hydrogels amendment.

7. Studied hydrogel appears to be highly effective for use as a soil conditioner on the lawn grass areas, to improve its tolerance to the low and medium saline conditions. These results should be however confirmed by the field trials.

\section{REFERENCES}

AKHTER J., MAHMOOD K., MALIK. A., MARDAN A., AHMAD M., IQBAL M. M. 2004: Effects of hydrogel amendment 
on water storage of sandy loam and loam soils and seedlings growth of barley, wheat and chickpea. Plant Soil Environ. 50. 2004 (10): 463-469.

ALPALSAN M., GUNES A. 2001: Interactive effects of boron and salinity stress on the growth, membrane permeability and mineral composition of tomato and cucumber plants. Plant and Soil. Vol. 236, Number 1: 123-128.

ALSHAMMARY S., QIAN Y., WALLNER S. 2004: Growth response of four turf grass species to salinity, Agricultural $\mathrm{Wa}$ ter Management 66 (2004): 97-111.

AL-HUMAID A.I. 2005: Effects of Hydrophilic Polymer on the Survival of Bottonwood (Conocarpus erectus) Seedlings Grown under Drought Stress. European Journal of Horticultural Science: 3 [Eng. summary].

ASADY G.H., SMUCKER A.J.M., ADAMS M.W. 1985: Seedlings test for the quantitative measurement of root tolerance to compacted soil. Crop Science, 25: 802-806.

BARANOWSKI T. 2006: Hydrożele w zieleni miejskiej. [Hydrogels on the green areas]. Zieleń Miejska. Numer 11/2006(3).

BARTNIK C. 2008: Wpływ hydrożelu Alscorb na przeżywalność siewek i sadzonek sosny pospolitej w warunkach suszy. [The influence of hydrogel on the survival rate of seedlings and the plants of the Pinus Syvestris L. during drought]. [In:] Studia $i$ Materialy Centrum Edukacji Przyrodniczo-Leśnej R. 10. Zeszyt 2(18)/2008.

BENEDYCKA Z., NOWAL G. 1998: Ekosorb jako źródło składników mineralnych dla roślin. [Ekosorb as a source of mineral compound for plants]. Zeszyty Problemowe Postępów Nauk Rolniczych 461: 131-136.

DIENER B., HEY S. 2005: Toxicological and environmental safety data Stockosorb®. Degussa AG - Stockhausen $\mathrm{GmbH}$. Krefeld [Eng. summary].

HADAM A. 2010: Effect of hydrogel on the grass species growing under drought stress. Challenges of modern technology.
October - December 2010, Vol. 1 (No 1), p. 3-6.

HAMEDA S., KIRKWOOD R., GRAHAM R. 1990: The Effects of a Hydrogel Polymer on the Growth of Certain Horticultural Crops under Saline Conditions. Journal of Experimental Botany, Vol. 42, Issue 7 [Eng. summary].

HAMEDA S., KIRKWOOD R., GRAHAM R. 1995: Studies on the effect on salinity and Hydrogels Polymer Tratments on the growth, Yield Production and solute accumulation in cotton and maize. J. King Saud. Univ., Vol. 7, Agri. Sci. (2): 222.

JOHNSON M.S. 1984: Effect of soluble salts on water absorption by gel-forming soil conditioners. J.Sci.Food Agri.,35:1063-1066 .

KACPERSKA A. 2005: Reakcje roślin na abiotyczne czynniki stresowe. [Plants reactions on abiotic stress agents]. [In:] Fizjologia roślin, (Reds.) Kopcewicz J., Lewak S., PWN, Warszawa, 612-657.

KANT A., TURAN M. 2010: Hydrogel substrate alleviates salt stress with increase antioxidant enzymes activity of bean (Phaseolus vulgaris L.) under salinity stress. African Journal of Agricultural Research, Vol. 6(3): 724.

KREEB K. 1979: Ekofizjologia roślin. [Ecophysology of plants]. Wyd. PWN, Warszawa: 5.

LECIEJEWSKI P. 2008: Wpływ wielkości dodatku hydrożelu na zmiany uwlgotnieniea i tempo przesychania gleby piaszczystej w warunkach laboratoryjnych. [The influence of the hydrogel addition on the changes of the sandy soils moisture and the dynamics of soil drying in the laboratory conditions]. [In:] Studia i Materiały Centrum Edukacji PrzyrodniczoLeśnej, R. 10. Zeszyt 2(18)/2008.

MORANT-MANCEAU A., PRADIER E., TREMBLIN G. 2004: Osmotic adjustment, gas exchanges and chlorophyll fluorescence of a hexaploid reticule and its parental species under salt stress. J. Plant Physiol. 161, 25-33. 
PALUSZEK J., ŻEMBROWSKI W. 2006: Wpływ hydrożelu Stockosorb na strukturę agregatową gleb erodowanych. [The influence of Stockosorb hydrogel on aggregate structure of erodated soils]. Roczniki Akademii Rolniczej w Poznaniu. Rolnictwo 2006. Zesz. 65 (375): 115-122.

PAWLUŚKIEWICZ B. 2009: Analiza możliwości wykorzystania gazonowych odmian traw do poprawy powierzchni trawiastych na obszarach zurbanizowanych. [Analysis of possibilities of turf grass cultivars application or improvement of grass surface on urbanized areas]. Wydawnictwo SGGW. Warszawa 2009: 20-24.

SROKA P. 2004: Polimery - lekarstwem na suszę. Aura 11: 5-7.

TRIPPEI R.R., GOERGE M.W., DUMROESE R.K., WENNY D.L. 1991: Brich seedling responce to irrigation frequency and a hydropholic polymer amendment in a container medium. Journal of Enviornment Horticulture 9: 119-123.

WALLACE A., WALLACE G.A. 1986: Effect of polymeric soil conditioners on emergence of tomato seedlings. Soil Sa, 141: 321-323.

WROCHNA M., GAWROŃSKA H., GAWROŃSKI S.W. 2005: Salt stress tolerance by ornamental plants considered for phytoremediation of urban areas. Acta Plant Physiology 27: 102.

WROCHNA M., MAŁECKA-PRZYBYSZ M., GAWROŃSKA H. 2010: Effect of the road de-icing salts with anti corrosion agents on selected plant species. Acta Sci. Pol., Hortorum Cultus 9(4) 2010: 171-182.

WU Y.,CHEN Q., CHEN M., CHEN J., WANG X. 2005: Salt-tolerant transgenic perennial ryegrass (Lolium perenne L.) obtained by Agrobacterium tumefaciensmediated transformation of the vacuolar $\mathrm{Na}$ super(+)/H super(+) antiporter gene. Plant Science. Vol. 169, no 1, p. 65-73.

WYSOCKI C., STAWICKA J. 2005: Trawy na terenach zurbanizowanych. [Grass in urban areas]. Lakarstwo $w$ Polsce (8): 227-236.
WYSOCKI C. 2008: Miasto jako specyficzne środowisko życia roślinności. [Urban areas as specific biotop for vegetations]. Nauka Przyroda Technologie 2008 Tom 2, Zeszyt 4.

ŻUREK G. 2006: Reakcja traw na niedobory wody - metody oceny i ich zastosowanie dla gatunków trawnikowych. Monografie i rozprawy naukowe. IHAR, $\mathrm{Nr} 25: 10$.

Streszczenie: Wplyw hydrożelu na wybrane gatunki traw gazonowych uprawianych $w$ warunkach stresu solnego. Hydrożele to substancje zdolne do gromadzenia dużej ilości wody, a wykorzystywane w praktyce mają łagodzić skutki suszy u roślin. Stosowane są od lat $\mathrm{w}$ ogrodniczej i rolniczej produkcji roślinnej, być może znajdą również zastosowanie w pielęgnacji zieleni przyulicznej. Obszary przyuliczne są szczególnie trudne do rozwoju roślinności - występuje tam jednak nie tylko deficyt wody, ale i zasolenie. Obecność nadmiernej ilości jonów w roztworze glebowym może tymczasem obniżać skuteczność działania hydrożelu, który oprócz wody sorbuje również kationy. Brak jest jednak wystarczającej wiedzy na ten temat. Istnieje zatem potrzeba kompleksowej oceny skuteczności hydrożeli w warunkach przyulicznych, uwzględniającej jednocześnie kilka czynników stresowych. Opracowanie to prezentuje wstępne wyniki badań działania hydrożelu w warunkach zasolenia na przykładzie reakcji wybranych gatunków traw gazonowych (kostrzewy czerwonej odm. Raisa, wiechliny łąkowej odm. Jarotka i życicy trwałej odm. Accent), które występują powszechnie na trawnikach przyulicznych. Doświadczenie wazonowe prowadzono przez cztery miesiące w kontrolowanych warunkach szklarniowych. Miarą skuteczności działania hydrożelu była ocena: wysokości darni, produkcji świeżej masy i stopnia uszkodzenia błon komórkowych traw narażonych na trzy poziomy zasolenia podłoża, w obecności i przy braku sorbentu. Uzyskane wyniki pozwoliły stwierdzić, że głównym czynnikiem determinującym niniejsze parametry było stężenie soli w podłożu. Reakcja ta była niezależna od obecności hydrożelu w podłożu. Mimo to w warunkach małego oraz średniego zasolenia dodatek sorbentu osłabił istotnie działanie stresu solnego na badane trawy. 
Stowa kluczowe: hydrosorbent, stres solny, susza, Mariola Wrochna trawniki przyuliczne

MS. received May 2011

Samodzielny Zakład Przyrodniczy Podstaw

Ogrodnictwa - SGGW

Authors' addresses:

ul. Nowoursynowska 159

02-787 Warszawa

Anna Hadam

mariola.wrochna@gmail.com

Zbigniew Karaczun

Katedra Ochrony Środowiska - SGGW

ul. Nowoursynowska 166,

02-787 Warszawa

e-mail: annah15@wp.pl

zbigniwe_karaczun@sggw.pl 